\title{
UNRAVELLING INGRAINED LEADERSHIP BEHAVIOURS AND STYLES IN WESTERN AND CENTRAL REGIONAL COLLEGES OF EDUCATION IN GHANA
}

\author{
Francis Hull Adams ${ }^{1}$ ( PhD); Jacob Issaka ${ }^{2}$ Barbara Amoako Kissi $^{3}$ \\ ${ }^{1}$ Department of Social Science, Holy Child College of Education, Takoradi, Ghana \\ ${ }^{2}$ Department of Arts and Social Sciences, Jasikan College of Education, Ghana \\ ${ }^{3}$ Department of Arts and Social Sciences, Accra College of Education, Accra, Ghana
}

DOI: 10.47760/cognizance.2021.v01i07.002

\begin{abstract}
This study examined leadership behaviours and leadership styles of students and tutors of colleges of education in Western and Central Regions of Ghana. Four specific leadership behaviours were discussed. These include: Team work, Discipline and Loyalty, Working relationships and Attitudes to welfare issues. Traditionally known leadership styles such as 'Democratic'; 'Autocratic' and Laissez faire were discussed in relation to both students and tutors. Percentage views of both students and tutors were taken about the leadership behaviours and leadership styles, then an independent sample T-test of male and female teacher trainees' views about the four thematic leadership behaviours were computed and discussed. The study also revealed that there is a correlation between students' participation in decision-making and their levels. There is also a correlation between Principals' leadership styles and the number of years spent in College. Recommendations made include: Measures should be put in place by College authorities to create democratic, open and transparent administration to ensure that both students and tutors operate without fear of being maligned or discriminated against in the performance of their duties. KEYWORDS: Leadership behaviours, Leadership styles
\end{abstract}

\section{INTRODUCTION}

Leadership has been defined by Clark (2012) as a process by which a person influences others to accomplish an objective and directs the organisation in a way that makes it more cohesive and coherent. Clark's definition of leadership has been reinforced by two other authors who share similar ideals about leadership. Zeitchik (2012) explained leadership as inspiring others to pursue one's vision within the parameters you set, to the extent that it becomes a shared effort, a shared vision, and a shared success. On his part, Kruse (2013) wrote that leadership is a process of social influence, which maximizes the efforts of others, towards the achievement of a goal.

It is important to note that all the definitions have a couple of processes in common: First, a person influences others through social influence, not power, to get something accomplished. Second, leadership requires others, who are not necessarily direct-reports, to get something accomplished, and thirdly, there is a need to accomplish something.

Kibet et al (2012) opined that all over the world, people are rejecting poor leadership and demanding more participatory and democratic approaches. According Standard (2009), as cited by Kibet et al (2012), school leadership is central in improving the efficiency and quality of schooling as it motivates teachers to work. In the African context, Salim (2002) as cited by Kibet et al (2012) also admitted that the continent is littered with failed institutions, mostly due to bad leadership. Devastating conflicts have been provoked and sustained by leadership factors. As we 


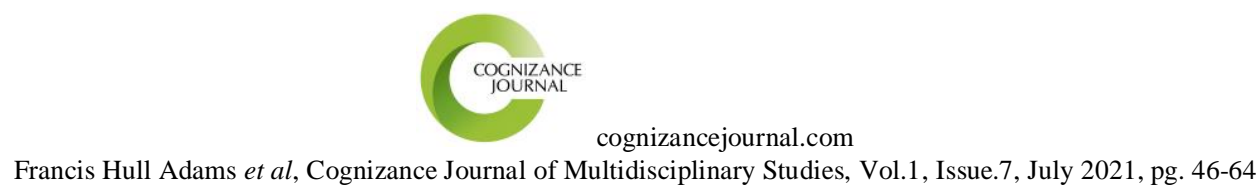

ISSN: 0976-7797

move on in the new century and Africa faces up to its challenges, it is important that the leadership factor be given due attention.

The school situation everywhere demands that the head teacher be effective in maintaining discipline by emphasizing goal oriented, relevant, immediate and consistent types of disciplined behaviour. Unqualified school managers are likely to be the major cause of many of the management related crises (Ndiku 2004). The primary role of school leadership is to maintain an efficient and transparent administration system to enhance instructional quality and discipline and develop links with the local community (Leithwood et al.2004).

Leadership at work in educational institutions is a dynamic process involving group tasks, collaboration and commitment in achieving goals in a particular context as stated by Cole (2002). Leadership recognizes the need for effective discipline in schools as it examines tasks to be accomplished and the individuals to execute them. This is achieved by the inclusion of greater reinforcement characteristics like recognition, conditions of service and morale building and remuneration. Whereas school leadership is well articulated by these authors, its correlation with leadership style cannot be underestimated.

\section{Conceptual Framework}

The conceptual framework used for the study was based on Robert Merton and Talcott Parsons' views on the theory of structural functionalism. The use of this theory enabled the researcher to ascertain the kind of influence that organisational culture has on people's behaviour, what is working in the Colleges, what is not working and what needs to be maintained or changed. Again, it explains the relationship between the organisational culture of a College of Education and the manifest and latent functions of education. More so, dysfunctional aspects of the College of Education also depend on the culture and the leadership styles and behaviours demonstrated by leaders.

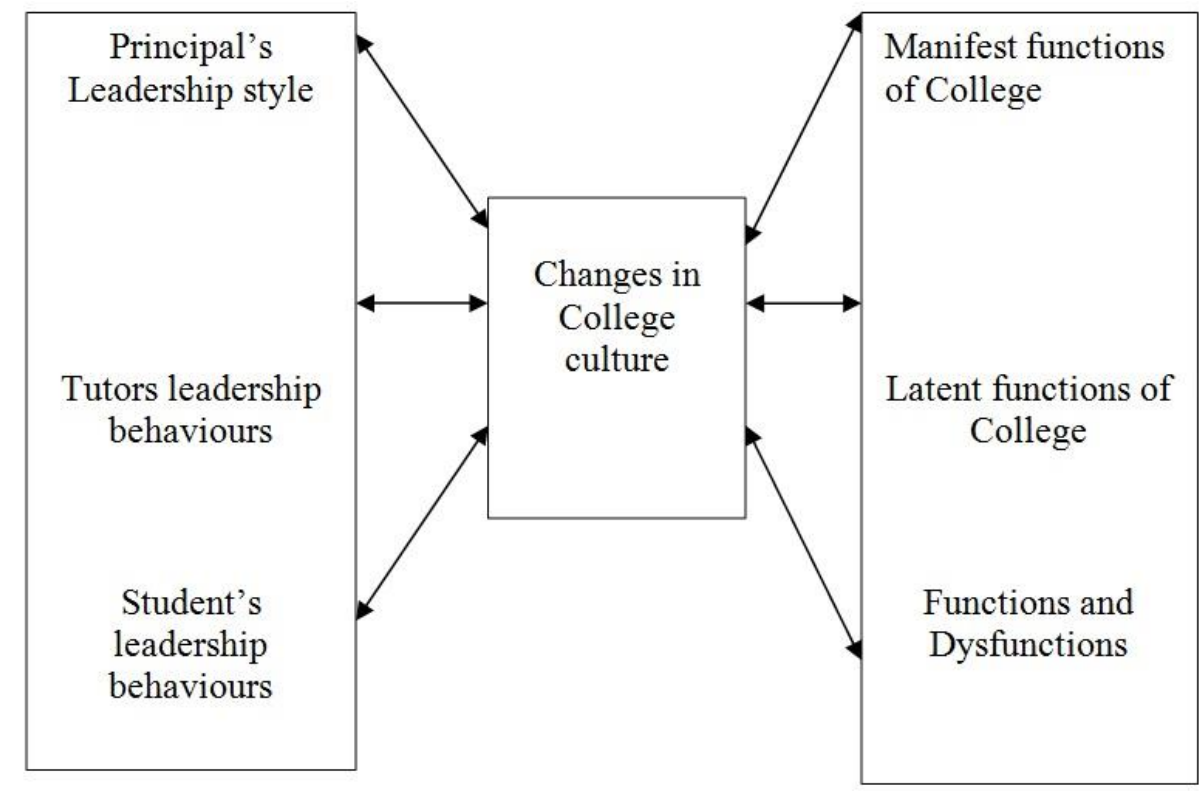

Figure 1: Changes in College Culture and Leadership Behaviours of Tutors and Students Based on Structural Functionalist Perspective 
cognizancejournal.com

Francis Hull Adams et al, Cognizance Journal of Multidisciplinary Studies, Vol.1, Issue.7, July 2021, pg. 46-64

ISSN: 0976-7797

College culture is a very powerful force which influences everybody in the college including the principal, the tutors, student leaders and the general student's body. The culture is however also affected by the leadership styles of the principal as well as the other behaviours of both staff and students. The principal's behaviour influences tutor's behaviour, student leaders' behaviours and general student's behaviours.

Applying functionalist ideas as postulated by Merton and Parsons to the social structure of Colleges of Education, it is clear that the Colleges of Education are independent institutions of their own and they have their own structures in place which perform various roles in helping the institutions to achieve their goals. The principal, staff (teaching and none teaching personnel), students' leaders and the general students' body constitute integral parts of each College of Education. They are the structures of the College as an institution. This agrees with functionalist's comparism of the society to an organism which has many parts for various purposes. This is so because the various structures in the Colleges perform unique but complementary functions.

The principal's leadership style, tutors and students' behaviours together exert some force on college culture. However, all these behaviours are also determined to a very large extent by the College culture especially in situations where the College has a strong culture. College culture is therefore a very powerful force which influences everybody in the college. Should any of the structures fail to perform their functions effectively it will result into what Merton described as dysfunctioning which would have repercussions on the other structures and hence the entire institution. Schaefer (2010) supports Merton's Functionalist view of society and further explains that structural Functionalism see leadership as a set of measurable behavior or skills. According to Schaefer, it includes all functional activities covering planning, organising, leading and controlling of the resources for their best utilization to make the institutional operations more cost-effective. It is clear from Schefer's view that with leadership, the emphasis is shifted from the individual to the role and behaviours that leaders portray towards the effectiveness of an organisation.

There is also a reciprocal relationship between the organisational culture of the College and the manifest and latent functions of the College. According to Robert Merton, manifest functions are those that are intended and recognized. These are functions which people assume and expect the institutions to fulfill. For example schools are expected to educate the children in the knowledge and skills that they need. The manifest functions are obvious, admitted and generally applauded (Schaefer, 2010). Latent functions are unrecognized and unintended functions. These are the unforeseen consequences of institutions. For example schools do not only educate the young but they also provide mass entertainment. Latent functions of an institution or partial structure may support the manifest functions for example the latent functions of religious institutions in the modern society include offering recreational activities and courtship opportunities to young people. Latent functions may be irrelevant to manifest functions for example, the big functions organised by schools may not impact the purpose of the education (Tetteh, 2010; Boundless Sociology. 2017)

In the College of Education, students are trained to become professional diploma teachers. To ensure this, conscious efforts are made to prepare the students in both content and pedagogical skills to enable them become competent teachers. In addition the students are taught about time 


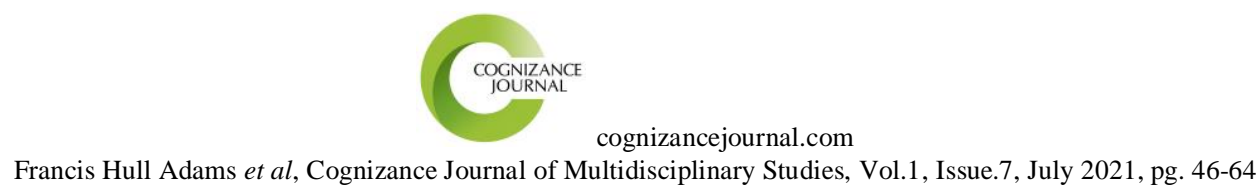

ISSN: 0976-7797

management and also about cleanliness. Aside these, entertainment programmes, sporting activities and club activities offer the learners opportunities to develop their skills in various ways. These are latent functions.

Another important part of the framework is functions and dysfunctions. Functionalists pay particular attention to functions performed by parts of a system especially its institutions, roles, cultural patterns, social norms and groups. Functionalists like Parsons and Merton were of the view that if a system is to survive, certain essential tasks must be performed. If these tasks are not performed, the system will fail to maintain itself and therefore perishes. Institutions in the society are therefore the principal structures whereby these critical tasks are organized, directed and executed. Merton believed that each institution is built around a standardized solution to a set of problems and that functions are the observed consequences of the existence of institutions that permit the adaptation of a system. These observed consequences that lessen the adaptation of a system is what the functionalist refer to as dysfunctions.

The Colleges of Education are societies of their own in which certain structures exist. The Colleges of Education are considered as societies because they have all the characteristics as societies. These include: first, each college has a definite population. Second, there is a network of social relationships in each college. Third, each college has an organisational culture of its own. Fouth, there is a "we-feeling" which exists among the members of each college. Lastly, there is a clearly defined system of authority in each College of Education. The notable structures in the colleges of education include; the principal, tutors, non teaching staff and students. Each of these structures performs distinct roles to determine the behaviour of the college. Dysfunction will occur in a situation where the various structures fail to perform their primary roles. For example, if the principal fails to administer the day-to-day affairs of the college there will be chaos on campus. If tutors fail to teach well, products of the college will bring dishonor to the institution in the field of work and if students also do not abide by college rules there will be lawlessness in the college. Changes in the culture of the college have the tendency to influence functions and dysfunctions. Positive changes in the organisational culture of the Colleges of Education will likely produce desirable functions performed by the structures of the Colleges of education. Negative changes will also likely lead to dysfunctions.

The following pseudonyms were adopted from Adams et al, 2021 to represent the target colleges throughout the study:

SOMCOE- State-Owned Mixed College of Education

FBMCOE- Faith-Based Mixed College of Education

FBSSCOE- Faith -Based Single Sex College of Education

\section{Objectives of the study}

The study aimed at achieving the following specific objectives:

1. To examine specific leadership behaviours portrayed by students and tutors of colleges of education

2. To ascertain the relationship between leadership styles and the number of years spent in college

3. To ascertain the relationship between students' participation in decision making and their number of years spent in the college 


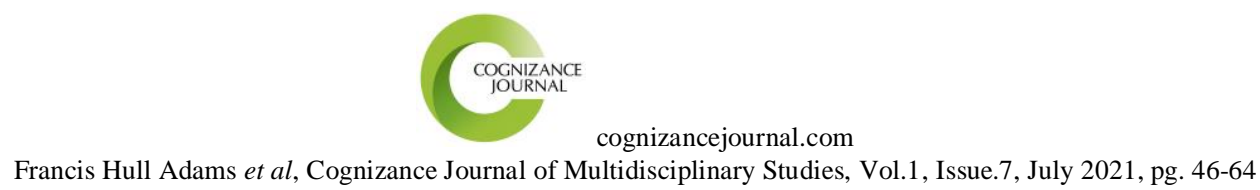

ISSN: 0976-7797

\section{Research Question}

What are the specific leadership behaviours portrayed by students and tutors of colleges of education?

\section{Hypotheses}

Ho: There is no significant relationship between tutors' leadership styles and the number of years spent in College.

Ho: There is no significant relationship between students' participation in decision-making and their number of years spent in the college

\section{METHODOLOGY}

The study used mainly a quantitative design with a survey. The target population for the study consisted of all teacher trainees and tutors in the Colleges of Education in Central and Western Regions of Ghana. A target population is that population which the researcher wants to generalize results about (Kumar 2011). Selected teacher trainees from FBMCOE, SOMCOE and FBSSCOE constituted the accessible population. A census of tutors in the three colleges was used for the study. The sample size of the study was 568 respondents, (450 students and 118 tutors.). The main research instrument used was Questionnaire. Both open-ended and closed ended questions were used. Use of questionnaires enabled the researcher to get reliable information from the target population mainly made up of literate people.

\section{RESULTS AND DISCUSSION}

Research Question: What are the specific leadership behaviours portrayed by students and tutors of colleges of education?

The study identified four specific leadership behaviours which include: Team work, Discipline and Loyalty, Working relationships and Attitudes to welfare issues. These have been thoroughly discussed as per the opinions and views expressed by the respondents.

\section{Team work}

Team work refers to the act of working effectively and efficiently as a member of a group. To be a team player, one needs to demonstrate certain group ideals such as honesty, loyalty, trust among others. Team work was examined from the perspectives of both students and tutors. Respondents were required to select from four scales of 'Strongly disagree', 'Disagree', 'Agree' and 'Strongly agree' in response to statements aligned to team work. Table 1 presents the views expressed by the respondents. Views of students were first discussed followed by the views of tutors.

Table 1: Team Work

\begin{tabular}{llccc}
\hline Item/Responses & $\begin{array}{l}\text { Strongly } \\
\text { Disagree }\end{array}$ & Disagree & Agree & $\begin{array}{l}\text { Strongly } \\
\text { Agree }\end{array}$ \\
\hline $\begin{array}{l}\text { SRC promotes team work } \\
\text { Faith-Based Single Sex College } \\
\text { of Education }\end{array}$ & 12.9 & 57.9 & 23.7 & 5.5 \\
$\begin{array}{l}\text { State-Owned Mixed College of } \\
\begin{array}{l}\text { Education } \\
\text { Faith-Based Mixed College of }\end{array}\end{array}$ & 12.6 & 67.9 & 17.4 & 2.1 \\
\hline
\end{tabular}




\begin{tabular}{|c|c|c|c|c|}
\hline Education & 12.9 & 45.0 & 37.1 & 5.0 \\
\hline Total & 12.8 & 57.0 & 26.0 & 4.2 \\
\hline \multicolumn{5}{|l|}{$\begin{array}{l}\text { Students enjoy working in } \\
\text { groups }\end{array}$} \\
\hline \multicolumn{5}{|l|}{ Faith-Based Single Sex College } \\
\hline of Education & 1.4 & 5.0 & 91.4 & 2.2 \\
\hline $\begin{array}{l}\text { State-Owned Mixed College of } \\
\text { Education }\end{array}$ & 43 & 750 & 207 & ת \\
\hline Faith-Based Mixed College of & & & & \\
\hline Education & 1.0 & 78.0 & 21.0 & 00.0 \\
\hline Total & 2.2 & 52.7 & 44.4 & 0.7 \\
\hline \multicolumn{5}{|l|}{ Collaborative work produce } \\
\hline \multicolumn{5}{|l|}{ Faith-based Single Sex College } \\
\hline State-Owned Mixed College of & & & & \\
\hline Education & 3.5 & 14.0 & 80.0 & 2.5 \\
\hline $\begin{array}{l}\text { Faith-Based Mixed College of } \\
\text { Education }\end{array}$ & 4.0 & 15.0 & 70.5 & 10.5 \\
\hline Total & 4.0 & 13.7 & 74.3 & 8.0 \\
\hline \multicolumn{5}{|l|}{$\begin{array}{l}\text { Faith-Based Single Sex College } \\
\text { of Education }\end{array}$} \\
\hline $\begin{array}{l}\text { State-Owned Mixed College of } \\
\text { Education }\end{array}$ & 00.0 & 10.0 & 70.0 & 20.0 \\
\hline $\begin{array}{l}\text { Faith-Based Mixed College of } \\
\text { Education }\end{array}$ & 00.0 & 40.0 & 50.0 & 10.0 \\
\hline Total & 00.0 & 30.0 & 60.0 & 10.0 \\
\hline $\begin{array}{l}\text { Tutors enjoy working in } \\
\text { groups }\end{array}$ & 00.0 & 26.7 & 60.0 & 13.3 \\
\hline \multicolumn{5}{|l|}{$\begin{array}{l}\text { Faith-Based Single Sex College } \\
\text { of Education }\end{array}$} \\
\hline $\begin{array}{l}\text { State-Owned Mixed College of } \\
\text { Education }\end{array}$ & 10.0 & 10.0 & 80.0 & 00.0 \\
\hline $\begin{array}{l}\text { Faith-Based Mixed College of } \\
\text { Education }\end{array}$ & 10.0 & 70.0 & 20.0 & 00.0 \\
\hline Total & 10.0 & 30.0 & 60.0 & 00.0 \\
\hline $\begin{array}{l}\text { Collaborative work promotes } \\
\text { leadership skills } \\
\text { Faith-Based Single Sex College } \\
\text { of Education }\end{array}$ & 10.0 & 36.7 & 53.3 & 00.0 \\
\hline $\begin{array}{l}\text { State-Owned Mixed College of } \\
\text { Education }\end{array}$ & 00.0 & 80.0 & 20.0 & 00.0 \\
\hline
\end{tabular}


cognizancejournal.com

Francis Hull Adams et al, Cognizance Journal of Multidisciplinary Studies, Vol.1, Issue.7, July 2021, pg. 46-64

ISSN: 0976-7797

\begin{tabular}{lllll}
\hline Faith-Based Mixed College of & 00.0 & 70.0 & 30.0 & 00.0 \\
Education & & & & \\
Total & 00.0 & 60.0 & 40.0 & 00.0 \\
& 00.0 & 70.0 & 30 & 00.0 \\
\hline
\end{tabular}

Source: Field survey, (2020)

Respondents were asked to indicate the extent to which they agree or disagree with the statement that 'SRC promotes team work'. Table 1 indicates that majority (57 percent) of the teacher trainees disagree with the statement. Analysis of College by College responses shows a unanimous rejection of the statement. $($ FBSSCOE: Disagree $=57.9 \%$; SOMCOE: Disagree $=67.9$; FBMCOE: $\mathrm{D}=45 \%$ ). Even though $45 \%$ of trainees in FBMCOE selected 'Disagree', a further $12.9 \%$ also selected 'Strongly Disagree" making up a total of $57.9 \%$ of the respondents in FBMCOE disagreeing with the perception that the SRC promotes team work. Lack of team work among the SRC is a recipe for disciplinary problems in the Colleges. Enforcement of College rules and regulations will depend to a great extent on the ability of the SRC to work as a team. The SRC working as a team has a number of advantages. Students' needs could be addressed quickly. The colleges are likely to experience more progress if the prefects and the administration work together.

Responding to the question of whether students enjoy working in groups, generally, 52.7\% constituting majority of the respondents disagreed with the assertion. However, on College basis, a whopping $91.4 \%$ of the respondents in FBSSCOE agreed with the statement whiles in SOMCOE and FBMCOE, the statement was rejected by $75 \%$ and $78 \%$ respectively. The implication is that if students do not enjoy working in groups, then team work will also suffer as discussed above. Collaborative work has been mentioned as a very important attitude which promotes leadership skills. Leadership at work in educational institutions is a dynamic process involving group tasks, collaboration and commitment in achieving goals in a particular context as stated by Ollenu, (2015) and Cole, (2002). Another issue inquired from respondents was whether collaborative works produce leaders. The statement received an overwhelming affirmative response $($ Agree $=74.3 \%)$. Though the respondents believe that collaborative work is good and that it can help produce leaders, it is interesting to know that students do not enjoy working in groups as presented in the earlier discussion.

Tutors responded to the same issues. First, majority of the tutor respondents $(60 \%)$ selected 'Agree' to the statement that tutors demonstrate team work. The second item sought to find out from the tutors whether they enjoy working in groups. Responding, 53.3\% of the tutors responded in the affirmative. However, responses from individual Colleges showed that most of the respondents in FBSSCOE and FBMCOE chose 'Agree' by $80 \%$ and $60 \%$ respectively whiles respondents in SOMCOE rejected the statement with 70\%. The last statement inquired from respondents whether collaborative work promotes leadership skills. Table 1 indicates that respondents from all the Colleges disagreed with the statement. 


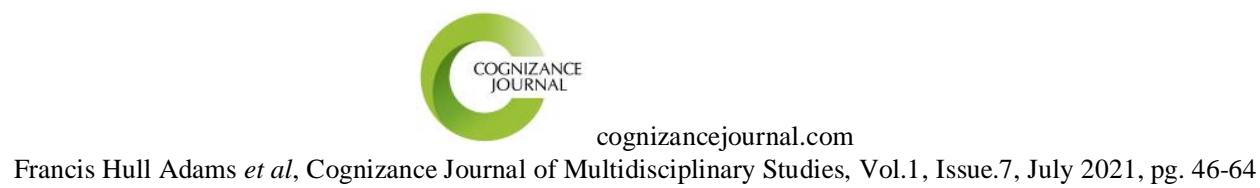

ISSN: 0976-7797

\section{Discipline and Loyalty}

Discipline can be explained as the readiness or ability to respect authority, and observe conventional or established laws of the society or of any other organization such as schools and colleges. Discipline therefore implies self-control, restraint, respect for self and respect for others. The purpose of discipline in the school context is to produce a breed of well cultured boys and girls who will develop not only respect for themselves and the society at large, but also respect for school authorities. Loyalty on the other hand is rooted in respect. Being faithful and committed to an issue, a group of people or an individual is an act of discipline. This study focused mainly on enforcement of College rules and regulation from both tutors' and trainees' perspectives. Table 2 presents views of respondents on discipline and loyalty.

Table 2: Discipline and Loyalty

\begin{tabular}{|c|c|c|c|c|}
\hline Item/Responses & $\begin{array}{l}\text { Strongly } \\
\text { Disagree }\end{array}$ & Disagree & Agree & $\begin{array}{l}\text { Strongly } \\
\text { Agree }\end{array}$ \\
\hline \multicolumn{5}{|l|}{$\begin{array}{l}\text { SRC enforces College rules and } \\
\text { regulations without } \\
\text { discrimination }\end{array}$} \\
\hline $\begin{array}{l}\text { Faith-Based Single Sex College of } \\
\text { Education }\end{array}$ & 6.4 & 70.7 & 22.9 & 00.0 \\
\hline $\begin{array}{l}\text { State-Owned Mixed College of } \\
\text { Education }\end{array}$ & 10.7 & 59.3 & 30.0 & 00.0 \\
\hline $\begin{array}{l}\text { Faith-Based Mixed College of } \\
\text { Education }\end{array}$ & $\begin{array}{l}5.0 \\
128\end{array}$ & 65.0 & 30.0 & 00.0 \\
\hline Total & 12.8 & 57.0 & 26.0 & 4.2 \\
\hline \multicolumn{5}{|l|}{$\begin{array}{l}\text { SRC is loyal to my College } \\
\text { authorities }\end{array}$} \\
\hline $\begin{array}{l}\text { Faith-Based Single Sex College of } \\
\text { Education }\end{array}$ & 2.9 & 4.3 & 73.6 & 19.3 \\
\hline $\begin{array}{l}\text { State-Owned Mixed College of } \\
\text { Education }\end{array}$ & 2.9 & 22.9 & 62.1 & 12.1 \\
\hline $\begin{array}{l}\text { Faith-Based Mixed College of } \\
\text { Education }\end{array}$ & 2.9 & 10.7 & 73.6 & 12.9 \\
\hline $\begin{array}{l}\text { Total } \\
\text { SRC set examples for others to }\end{array}$ & 2.2 & 52.7 & 44.4 & 0.7 \\
\hline Table 2 continued & & & & \\
\hline $\begin{array}{l}\text { Education } \\
\text { State-Owned Mixed College of }\end{array}$ & 2.1 & 3.6 & 62.1 & 32.1 \\
\hline $\begin{array}{l}\text { Education } \\
\text { Faith-Based Mixed College of }\end{array}$ & 2.1 & 2.9 & 68.6 & 26.4 \\
\hline
\end{tabular}


cognizancejournal.com

Francis Hull Adams et al, Cognizance Journal of Multidisciplinary Studies, Vol.1, Issue.7, July 2021, pg. 46-64

ISSN: 0976-7797

\begin{tabular}{|c|c|c|c|c|}
\hline $\begin{array}{l}\text { Education } \\
\text { Total }\end{array}$ & $\begin{array}{l}2.1 \\
4.0\end{array}$ & $\begin{array}{l}3.6 \\
13.7\end{array}$ & $\begin{array}{l}62.1 \\
74.3\end{array}$ & $\begin{array}{l}32.1 \\
8.0\end{array}$ \\
\hline \multicolumn{5}{|l|}{$\begin{array}{l}\text { Tutors enforce College rules and } \\
\text { regulations }\end{array}$} \\
\hline Holy Child College of Education & & & & \\
\hline $\begin{array}{l}\text { State-Owned Mixed College of } \\
\text { Education }\end{array}$ & 00.0 & 20.0 & 80.0 & 00.0 \\
\hline Faith-Based Mixed College of & 10.0 & 20.0 & 70.0 & 00.0 \\
\hline Education & 00.0 & 00.0 & 60.0 & 40.0 \\
\hline Total & 3.3 & 13.3 & 70.0 & 13.4 \\
\hline \multicolumn{5}{|l|}{ Tutors are loyal to College } \\
\hline Management Board & & & & \\
\hline $\begin{array}{l}\text { Faith-Based Single Sex College of } \\
\text { Education }\end{array}$ & 10.0 & 80.0 & 10.0 & 00.0 \\
\hline $\begin{array}{l}\text { State-Owned Mixed College of } \\
\text { Education }\end{array}$ & 10.0 & 70.0 & 20.0 & 00.0 \\
\hline $\begin{array}{l}\text { Faith-Based Mixed College of } \\
\text { Education }\end{array}$ & 10.0 & 80.0 & 00.0 & 00.0 \\
\hline Total & 00.0 & 70.0 & 30.0 & 00.0 \\
\hline $\begin{array}{l}\text { Tutors set examples for others to } \\
\text { emulate }\end{array}$ & & & & \\
\hline $\begin{array}{l}\text { Faith-Based Single Sex College of } \\
\text { Education }\end{array}$ & 10.0 & 90.0 & 00.0 & 00.0 \\
\hline $\begin{array}{l}\text { State-Owned Mixed College of } \\
\text { Education }\end{array}$ & 10.0 & 70.0 & 20.0 & 00.0 \\
\hline $\begin{array}{l}\text { Faith-Based Mixed College of } \\
\text { Education }\end{array}$ & 10.0 & 60.0 & 30.0 & 00.0 \\
\hline Total & 10.0 & 73.3 & 16.7 & 00.0 \\
\hline
\end{tabular}

Source: Field survey, (2020)

Table 2 shows how students and tutors responded to issues relating to discipline and loyalty in the Colleges of Education. The issue of whether the SRC and tutors enforce College rules and regulations without discrimination received different responses. Whereas students disagree with the statement (57\%), tutors on the other hand supported the assertion (70\%). The literature however, supports the assertion. The SRC perform a number of functions all aimed at seeking the interest and welfare of students. Besides they also resolve conflicts and settle disputes among students, and enforce rules and regulations governing the institutions and their bodies (Jeruto et al (2011), SRC constitutions of UCC, HCCE, 2013 CUC, 2015). The second issue deals with loyalty to College. Majority of tutors and students selected "disagree" (Students: 52.7\%, Tutors: 70\%). Again, student respondents agreed that the College SRC set examples for others to emulate (74\%) whiles tutors on the other hand disagreed with it by $73 \%$.

The literature supports the assertion that leaders, both students and tutors must set examples for others to emulate. According to Adelke ( 2015 ), the leader has a negative attitude towards the stakeholders he/she is likely to adopt an exclusive management approach, but if the attitude is 


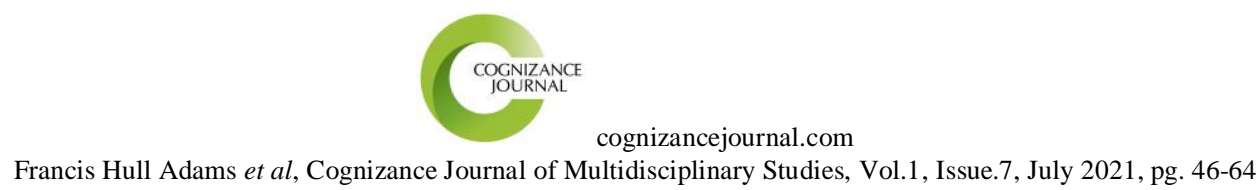

ISSN: 0976-7797

positive, the leader is likely to apply an all inclusive style to attain organisational goals. Schein ( 1992 ) also revealed that a leader who is deliberate in role modeling, teaching and coaching encourages a positive culture. This applies to both student leaders and tutors in the Colleges of Education. However, the extent of behavior demonstrated by the individual in the work place is influenced by the organisational culture ( Ruben \& Gigliotti, 2016 ).

\section{Working Relationships}

One of the important factors which ensure effective productivity is having a good working relationship with all. In the College of Education, students, student leaders, tutors and the Principal are key partners who should be able to establish cordial relationship. Table 3 presents trainees and tutors opinions as regards working relationships in the College and its impact on the schools climate.

Table 3: Working Relationships

\begin{tabular}{|c|c|c|c|c|}
\hline Item/Responses & $\begin{array}{l}\text { Strongly } \\
\text { Disagree }\end{array}$ & Disagree & Agree & $\begin{array}{l}\text { Strongly } \\
\text { Agree }\end{array}$ \\
\hline $\begin{array}{l}\text { Cordial relationship exists } \\
\text { between students and their } \\
\text { leaders }\end{array}$ & & & & \\
\hline $\begin{array}{l}\text { Faith-Based Single Sex College of } \\
\text { Education }\end{array}$ & 5.7 & 66.4 & 25.7 & 2.2 \\
\hline $\begin{array}{l}\text { State-Owned Mixed College of } \\
\text { Education }\end{array}$ & 9.3 & 73.0 & 17.7 & 00.0 \\
\hline $\begin{array}{l}\text { Faith-Based Mixed College of } \\
\text { Education }\end{array}$ & 2.1 & 24.3 & 72.9 & 0.7 \\
\hline Total & 5.7 & 54.6 & 38.7 & 1.0 \\
\hline
\end{tabular}

\section{Cordial relationship exist between student leaders and their tutors}

Faith-Based Single Sex College of Education

$\begin{array}{llll}6.4 & 29.3 & 48.6 & 15.7\end{array}$

State-Owned Mixed College of

Education

$\begin{array}{llll}2.1 & 2.9 & 89.3 & 5.7\end{array}$

Faith-Based Mixed College of

Education

4.3

Total

2.2

Cordial relationship exist

52.7

44.4

0.7

between Principal and tutors

Faith-Based Single Sex College of

Education

$\begin{array}{llll}00.0 & 90.0 & 10.0 & 00.0\end{array}$

State-Owned Mixed College of

Education

$\begin{array}{llll}10.0 & 70.0 & 20.0 & 00.0\end{array}$


cognizancejournal.com

Francis Hull Adams et al, Cognizance Journal of Multidisciplinary Studies, Vol.1, Issue.7, July 2021, pg. 46-64

ISSN: 0976-7797

\begin{tabular}{|c|c|c|c|c|}
\hline $\begin{array}{l}\text { Faith-Based Mixed College of } \\
\text { Education }\end{array}$ & 00.0 & 60.0 & 40.0 & 00.0 \\
\hline Total & 3.3 & 73.3 & 23.4 & 00.0 \\
\hline $\begin{array}{l}\text { Cordial relationship exist } \\
\text { between students and tutors }\end{array}$ & & & & \\
\hline $\begin{array}{l}\text { Faith-based Single Sex College of } \\
\text { Education }\end{array}$ & 10.0 & 80.0 & 10.0 & 00.0 \\
\hline $\begin{array}{l}\text { State-Owned Mixed College of } \\
\text { Education }\end{array}$ & 10.0 & 70.0 & 20.0 & 00.0 \\
\hline $\begin{array}{l}\text { Faith-based Mixed College of } \\
\text { Education }\end{array}$ & 10.0 & 80.0 & 00.0 & 10.0 \\
\hline Total & 10.0 & 76.6 & 10.0 & 3.3 \\
\hline
\end{tabular}

Source: Field survey, (2020)

Table 3 presents four kinds of working relationships existing in the Colleges of Education. They include; Working relationship between students and their leaders ( SRC ), relationship between student leaders and tutors, relationship between students and tutors and relationship between principal and tutors. Respondents were asked to indicate whether there existed cordial relationships among the various parties. First, most of the respondents disagreed that there is cordial relationship between students and their leaders ( 54.6\%). Again, 52.7\% of the respondents disagreed that cordial relationship exist between students leaders and tutors. Relationship between the principal and tutors also showed a decline. Majority of the respondents selected Disagree' (73.3\%) . More so, $76.7 \%$ of the respondents indicated that there was also no cordial relationship between students and tutors.

Working relationships are very important in every organisation. Good working relationships have the potency of raising productivity in organisations including colleges of education where the greater part of the work deals with interactions.

\section{Attitudes to Welfare Issues}

Welfare issues of students and tutors are crucial to every educational institution. Welfare issues are ingrained in the concept of motivation. Motivation has been defined by a number of authors. Kelley opined that "Motivation has to do with the forces that maintain and alter the direction, quality and intensity of behavior" ( p.279). On their part, Monday et al explained that motivation is the process of influencing or stimulating a person to take action that will accomplish desired goal. Generally, motivation can be equated with needs, wants, desires, wishes, aspirations and attitudes which arouses an organisms behavior towards attainment of some goals. A number of welfare issues which borders on motivation have been addressed in Table 4. 
Table 4: Attitudes to Welfare Issues

\begin{tabular}{|c|c|c|c|c|}
\hline Item/Responses & $\begin{array}{l}\text { Strongly } \\
\text { Disagree }\end{array}$ & Disagree & Agree & $\begin{array}{l}\text { Strongly } \\
\text { Agree }\end{array}$ \\
\hline $\begin{array}{l}\text { Student leaders broadly consult } \\
\text { before taking decisions about } \\
\text { student's welfare }\end{array}$ & & & & \\
\hline $\begin{array}{l}\text { Faith-Based Single Sex College of } \\
\text { Education }\end{array}$ & 6.4 & 28.6 & 64.3 & 0.7 \\
\hline $\begin{array}{l}\text { State-Owned Mixed College of } \\
\text { Education }\end{array}$ & 15.0 & 1.9 & 41.0 & 42.1 \\
\hline Faith-Based Mixed College of & & & & \\
\hline $\begin{array}{l}\text { Education } \\
\text { Total }\end{array}$ & $\begin{array}{l}6.4 \\
9.3\end{array}$ & $\begin{array}{l}37.2 \\
22.6\end{array}$ & $\begin{array}{l}55.7 \\
53.6\end{array}$ & $\begin{array}{l}0.7 \\
14.5\end{array}$ \\
\hline $\begin{array}{l}\text { Student leaders take initiative to } \\
\text { address issues concerning } \\
\text { students' welfare } \\
\text { Faith-Based Single Sex College of }\end{array}$ & & & & \\
\hline $\begin{array}{l}\text { Faith-Based Single Sex College of } \\
\text { Education }\end{array}$ & 10.0 & 85.0 & 4.3 & 0.7 \\
\hline $\begin{array}{l}\text { State-Owned Mixed College of } \\
\text { Education }\end{array}$ & 2.1 & 31.4 & 62.1 & 4.4 \\
\hline Faith-Based Mixed College of & & 171 & 764 & 43 \\
\hline $\begin{array}{l}\text { Eaucation } \\
\text { Total }\end{array}$ & $\begin{array}{l}2.2 \\
4.8\end{array}$ & 44.5 & 47.6 & $\begin{array}{l}4.5 \\
3.1\end{array}$ \\
\hline $\begin{array}{l}\text { Student leaders always take } \\
\text { proposals from administration } \\
\text { as against that of students } \\
\text { Faith-Based Single Sex College of }\end{array}$ & & & & \\
\hline Education & 23.6 & 59.3 & 14.3 & 2.8 \\
\hline $\begin{array}{l}\text { State-Owned Mixed College of } \\
\text { Education }\end{array}$ & 2.2 & 31.4 & 62.1 & 4.3 \\
\hline $\begin{array}{l}\text { Faith-Based Mixed College of } \\
\text { Education }\end{array}$ & 21 & 171 & 764 & 44 \\
\hline Total & 9.3 & 35.9 & 50.9 & 3.9 \\
\hline $\begin{array}{l}\text { Principal's broadly consults } \\
\text { before taken decisions about } \\
\text { tutor's welfare } \\
\text { Faith-Based Single Sex College of } \\
\text { Education }\end{array}$ & 00.0 & 70.0 & 10.0 & 20.0 \\
\hline
\end{tabular}


cognizancejournal.com

Francis Hull Adams et al, Cognizance Journal of Multidisciplinary Studies, Vol.1, Issue.7, July 2021, pg. 46-64

ISSN: 0976-7797

State-Owned Mixed College of

Education

$\begin{array}{llll}00.0 & 50.0 & 50.0 \quad 00.0\end{array}$

Faith-Based Mixed College of

Education

00.0

40.0

50.0

10.0

Total

00.0

53.3

36.7

10.0

Principals take initiatives to address issues concerning tutors' welfare

Faith-Based Single Sex College of

Education

$\begin{array}{llll}00.0 & 00.0 & 80.0 & 20.0\end{array}$

State-Owned Mixed College of

Education

10.

70.0

$20.0 \quad 00.0$

Faith-Based Mixed College of

Education

10.0

80.0

(1)

Total

6.7

50.0

10.0

00.0

Principal always implements proposals without considering the views of tutors

Faith-Based Single Sex College of

Education

$\begin{array}{llll}5.0 & 25.0 & 55.0 & 15.0\end{array}$

State-Owned Mixed College of

Education

10.0

47.0

29.0

14.0

Faith-Based Mixed College of

Education

15.0

30.0

50.0

5.0

Total

10.0

34.0

44.7

11.3 
A number of issues with regard to students' and tutors' welfare were raised by the respondents. First, trainees were asked to indicate whether students' leaders broadly consult them before taking decisions about students' welfare. Tutors were also asked to indicate whether the principals broadly consult tutors before taking decisions about their welfare. Responding, majority of the trainees selected 'Agree' and 'strongly agree' (68.1\%). However, on the part of the tutors the story was different as most of the tutor respondents selected 'Disagree' (53.3\%). In specific terms, as tutors in FBSSCOE disagreed (70\%), their counterparts in SOMCOE and FBMCOE were torn between agreeing and disagreeing. This is so because in both institutions, the measures of "Agree" and Disagree" received a percentage scores of $50 \%$ each.

Table 4 presents another issue about students and tutors welfare which centres on whether initiatives are readily taken by both students' leaders and College principals to address students and tutors' welfare. In response, both students and tutor respondents disagreed by $49.3 \%$ and $56.7 \%$ respectively. This implies student leaders to some extent take steps to address students' welfare issues. College principals on the other hand do not actually take welfare issues of students and tutors serious.

The last but not the least issue captured in Table 4 is about student leaders taking proposals from College administration and implementing them against students' interest. On the part of tutors, they were required to indicate whether their views were sought for by College principal when implementing proposals and decisions about the College. As represented in Table 4, both students and tutors responded in the affirmative showing that their views are sought for by the leaders. However, it is one thing seeking people's views and opinions and another thing implementing them. It can be inferred from the responses given that the students and tutors have a problem of implementation of their views and not the soliciting of their views.

Table 5: Independent Sample T-Test of Male and Female Teacher Trainees' Views about Leadership Behaviours in the 3 Colleges of Education

\begin{tabular}{|c|c|c|c|c|c|c|}
\hline Variable & Gender & Mean & SD & $\mathrm{df}$ & $\mathrm{t}$ & $\mathrm{P}$ \\
\hline $\begin{array}{l}\text { Teacher trainees' views } \\
\text { about Leadership } \\
\text { behaviours in the } 3\end{array}$ & Male: 200 & 13.2 & 1.56 & 56 & 2.602 & 0.509 \\
\hline Colleges of Education & Female: 250 & 13.8 & 1.31 & & & \\
\hline
\end{tabular}

Source: Field survey, (2020)

An Independent T-test was conducted to ascertain the difference in terms of views expressed by males and females teacher trainees about leadership behaviours in the three Colleges of 


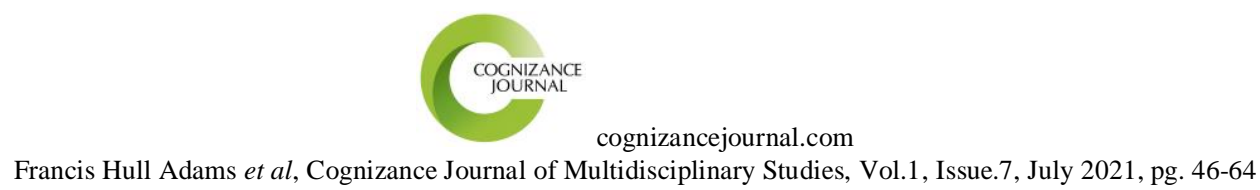

ISSN: 0976-7797

Education. Alpha level of 0.05 was used to determine the significant level of the Means. Table 36 indicates that views expressed by females had a higher mean value as compared to views expressed by males (Females: Mean= 13.8, $\mathrm{SD}=1.31$, Males: Mean= 13.2, $\mathrm{SD}=1.56$ ). This means female views were stronger in all the Colleges of Education used for the study.

Levens' test for equality of variances was 0.419 which was not significant as compared with the alpha of 0.05 . So there was no significant difference in the variances of the two groups (Males \& Females) in the three Colleges of Education. The row equal variance assumed was therefore used to determine the t-test for equality of Means. The computed T-test for equality of Means resulted in 0.509 as represented in Table. The figure is greater than 0.05 hence there was no significance difference between the views expressed by males and female students about leadership behaviours in the 3 Colleges of Education.

A correlation was run to ascertain the relationship between Principal's leadership styles and the number of years spent in College. Three types of leadership styles were correlated against Number of years spent in College. The leadership styles were; democratic, autocratic and lesser air. The Correlation coefficients are presented in Table 6 below.

Table 6: Correlation Matrix of Principals' Leadership Styles and the Number of Years Spent in College.

\begin{tabular}{llllll}
\hline Variables & $\mathrm{X}_{1}$ & $\mathrm{X}_{2}$ & $\mathrm{X}_{3}$ & $\mathrm{Y}_{1}$ & $\mathrm{Y}_{2}$ \\
\hline $\mathrm{X}_{1}$ & 1 & .101 & .012 & $.869^{* *}$ & $.169^{* *}$ \\
$\mathrm{X}_{2}$ & & 1 & .102 & $.412^{* *}$ & $-.974^{* * *}$ \\
$\mathrm{X}_{3}$ & & & 1 & .013 & $.785^{* *}$ \\
$\mathrm{Y}_{1}$ & & & & 1 & .116 \\
$\mathrm{Y}_{2}$ & & & & & 1 \\
\hline
\end{tabular}

**Correlation is significant at 0.05 level. 2 tailed

Source: Field survey, (2020)

$\mathrm{X}_{1:}$ Democratic style of leadership

$\mathrm{X}_{2}$ : Autocratic style of leadership

$\mathrm{X}_{3:}$ Lesser faire style of leadership

$\mathrm{Y}_{1:}$ Number of years spent in College (Below 5 years)

$\mathrm{Y}_{2:}$ Number of years spent in College (5- 10 years)

Table 6 gives the Coefficient (r) as .869 for Democratic style against Number of years spent (below 5 years). The $\mathrm{P}$ value is .000 . P: $000<0.05$ hence there is significant relationship between the two variables. This implies the less number of years spent as principal the more democratic one becomes. However, Number of years spent between 5 and 10 years run against democratic style of leadership yielded a coefficient of .169 which indicates a low strength. In spite of the low strength, the association is significant because the P-value is 0.03 . 


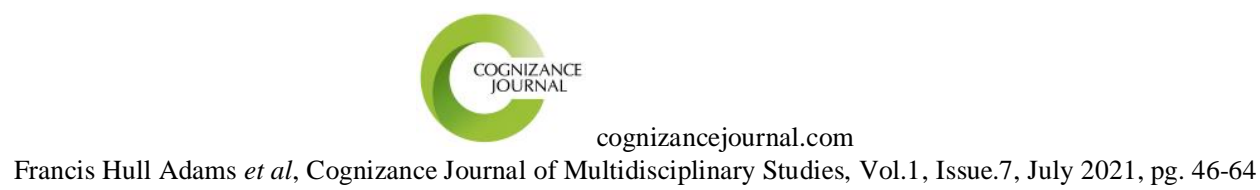

ISSN: 0976-7797

Autocratic style and Number of years spent as principal showed both moderate and strong relationships. As indicated in Table 6, below 5 years showed a relationship of .412 which is moderate whiles five years and above showed a relationship of .974, a very strong coefficient. This implies, the less the number of years spent as principal, the less autocratic one becomes and the more the number of years as principal the more autocratic one becomes. Correlation was again run between Lesserfair style of leadership and number of years spent in College. The result showed that there was no relationship between 'Lesserfair style and number of years spent in College below 5 years. However, number of years spent above 5 years showed a positively strong relationship. This implies, the less the number of years spent in College, the less Lesserfair one becomes and the more the number of years, the more the leader practices lesserfair

Student' participation in decision-making was correlated with category of student to determine whether significant relationships existed. Decision-making was measured in three key areas; representation on college committees, solicit of students views on important issues, and incorporation of students' views in decision-making. These issues were run against the category of students to determine the extent at which they relate in Table 9. The hypothesis tested was:

Ho: There is no significant relationship between students' participation in decision-making and their levels.

\section{Table 7: Correlation Matrix of Category of Students and their Participation in Decision-} Making in the Three Colleges of Education

\begin{tabular}{llllll}
\hline Variables & $\mathrm{D}_{1}$ & $\mathrm{D}_{2}$ & $\mathrm{D}_{3}$ & $\mathrm{~L}_{1}$ & $\mathrm{~L}_{2}$ \\
\hline $\mathrm{D}_{1}$ & 1 & .012 & .131 & .113 & $.962^{* *}$ \\
$\mathrm{D}_{2}$ & 1 & .055 & $.212^{* *}$ & $.906^{* *}$ \\
$\mathrm{D}_{3}$ & & 1 & 1 & -.134 & $-.816^{* *}$ \\
$\mathrm{~L}_{1}$ & & & & 1 & .106 \\
$\mathrm{~L}_{2}$ & & & & & 1 \\
\hline
\end{tabular}

$* *$ Correlation is significant at 0.05 levels. 2 tailed

Source: Field survey, (2020)

$\mathrm{D}_{1:}$ Representation on College Committees

$\mathrm{D}_{2:}$ Administration seeks views of students on important issues

$\mathrm{D}_{3:}$ Incorporation of students' views into administration

$\mathrm{L}_{1}$ : Number of category of students (Level 100)

$\mathrm{L}_{2}$ : Number of category of students (Level 200)

Representation on College Committees versus category of student showed a correlation coefficient of .962 for level 200 whiles level 100 showed .113. The direction of the relationships is positive. However, the relationship between level 200 and their membership of committees showed a significant association. This implies students are represented more on College committees as they get to level 200 and vice-versa. Students are less represented on College committees as they enter level 100. 
cognizancejournal.com

Francis Hull Adams et al, Cognizance Journal of Multidisciplinary Studies, Vol.1, Issue.7, July 2021, pg. 46-64

ISSN: 0976-7797

"Administration seeks views of students" versus "category of student" showed a coefficient of .212 for level 200 and .906 for level 100 students. It is clear from the statistics that there is a strong relationship between category of students in level 200 and the fact that administration seeks views of students. This means the more students get to level 200, the more their views are sought for by the College administration, the more students remain in Level 100, and the less their views are represented.

Incorporation of students' view against category of students yielded coefficients of .816 and .134 for levels 200 and level 100 respectively. It can be said that the more students get to level 200 the more they are represented on College Committees.

Incorporation of students' views into decisions and representation on College committees are all part of the culture of the Colleges of Education when it comes to decision making. The findings in this respect indicates that category of student has some influence on decision making. It also denotes that College administration prefer working with level 200 students more than level 100 students. Sapienzo ( 1985 ) opined that one of the most important components of organisational culture is shared beliefs and these beliefs influence decision-making. Writing on what culture can do Wilkins ( 1983 ) explained that the type of leadership exhibited in a school determines whether the school has a strong or weak culture.

This chapter examined leadership styles and behaviours of students and tutors in the Colleges of Education. Specific leadership behaviours discussed include; Team work, Discipline and loyalty, working relationships and Attitudes to welfare issues. Discussions revealed that apart from attitudes to welfare issues which the respondents did not show much commitment to, they were committed to ensuring team work, promoting discipline and enhancing good working relationships among all.

The types of leadership styles discussed include; Democratic, Autocratic and Laissez faire. Democratic and Autocratic styles were the main concern of the respondents. Whiles students agreed that democratic system of administration is run by the SRC, tutors agreed that the principals are largely autocratic.

\section{CONCLUSIONS AND RECOMMENDATIONS}

It can be concluded from the study that leadership behaviours demonstrated by both students and tutors in the Colleges of Education aggregates to determine the type of leadership style. The four major behaviours which emerged from the study includes; Teamwork- tutors promoted team work whilst student leaders lacked it; Discipline and loyalty- tutors enforced rules and regulations without discrimination but student leaders did not show much firmness; three categories of working relationships that emerged were; student leaders and tutors, students and tutors and students and student leaders; response to welfare issues- both student leaders and tutors showed little commitment to addressing welfare issues of members.

These findings of the study totally agree with the behavioural theory of leadership which emphasizes that leaders are made not born. The study demonstrated a practical application of the behavioural theory with emphasis on the fact that leaders' behaviour affects their performance. However, the outcome of the study did not indicate which style of leadership is significant in enabling one group to work better than another. 
cognizancejournal.com

Francis Hull Adams et al, Cognizance Journal of Multidisciplinary Studies, Vol.1, Issue.7, July 2021, pg. 46-64

ISSN: 0976-7797

\section{REFERENCES}

[1]. Adams et al, ( 2021). Analytical Study of the Organisational Culture- Related Practices in Colleges of Education in Western and Central Regions of Ghana. Research on Humanities and Social Sciences, 11, (13), $1-15$

[2]. Adelke, M.N. (2015). Culture, School Climate and Welfare system. Journal of Humanitarian issues, 4, (2), 6-8

[3]. Agin, E. \& Gibson, T. (2014). Developing an innovative culture. T+D 64 (7), 52-55

[4]. Anaisie, B. (2016). Routine practices of college students. International Journal of Quality Intervention. 3, (2), 2-3

[5]. Belias, D. \& Koustelios, A. (2014). The impact of leadership and change management strategy

[6]. Bevan, R. (2011). Keeping Change on Track. The Journal for participation, 34 (1). 4-9

[7]. Bipembi, E. (2014). Relationship between leadership style and school climate. Management Journal, 6 (2), 4-7

[8]. Blay, F. (2015). The Role of Culture and leadership in institutions of learning. Journal of Interdisciplinary Studies, 8 (2), 6-8.

[9]. Boateng, C. (2012). Leadership styles and effectiveness of principals of Vocational Technical Institutes in Ghana. American Journal of Contemporary Research. 2 (3)

[10].Bogler, R. (2001). The influence of leadership style on teacher job satisfaction. Educational Administration Quarterly. 35, (6) 62-683.

[11].Boundless Sociology (2017). The Functionalist perspectives. Retrieved on 1-2-17 from www. Boundless.com/sociology/textbooks

[12].Clark, F. C. (2012). Looking for the ideal leadership style in organisations. The Voices of Yearning leaders, $13,(7), 70-75$

[13].Cole, G.A. (2002). Personnel and human resource management (5the Edition).Ashford Colour Press

[14].Dereli, M. (2003). A survey research of leadership styles of Elementary School principals. A master's thesis unpublished.

[15].Everard, B. \& Morris, G. (1990). Effective School Management. London: Paul Chapman Publishing Ltd.

[16].Farh, J. L., Cheng, B. S., Chou, L. F., \& Chu, X. P. (2006). Authority and benevolence: Employees' responses to paternalistic leadership in China. In A. S. Tsui, Y. Bian, \& L. Cheng (Eds.), China's domestic private firms: Multidisciplinary perspectives on management and performance 62 (101) 230-260. New York: Sharpe.

[17].Finish Higher Education Evaluation Council. (2008). Audits of quality assurance systems of Finish higher education institutions. Audit manual for 2008-2011. Retrieved 29 Nov, 2010, from http://www.kka.fi/pdf/julkaisut/ kka1007.pdf

[18].Geir, M. T. ( 2016). Leadership in extreme context: Transformational leadership, performance beyond expectations? Journal of Leadership and organizational Studies, 23, (3), 234-247

[19].Gursel, M. \& Negis- Isk, A. (2013). Organisational culture in a successful primary school: An Ethnographic case study. Journal of Educational Sciences: Theory and Practice, 13, (10), 221-228

[20].HCCE SRC Constitution (2013). Roles of the Executive members. Takoradi, Ad-Technology

[21].Jeruto, T.A., Amock, P., \& Brand, S. (2011). Extent of Student participation in Decision-making in Secondary Schools in Kenya. International Journal of Humanities and Social Science. 1 (21)

[22].Johannson, F.K. ( 2014). Promoting effective leadership, a global perspective. Journal of Multidisciplinary nature, $6,(7), 21-32$

[23].Katz, D., \& Kahn, R.L. (2003). The social psychology of organizations (2nd ed.), New York: Wiley.

[24].Kibet, M.J., Kindiki, J.K, Kitilit, J.K \& Sang, J.K. ( 2012 ) Principal leadership and its impact on students' discipline in Kenya Secondary schools: a case of Koibatek district. Nkanyiso, Jnl Human and Soc Sci, 2 ( 2 )

[25].Koustelios, A. \& Belias, D. ( 2014 ). The impact of leadership and change management strategy on organisational culture. European Scientific Journal, 10 ( 7 ), 1857-7881

[26].Kouzes, J. M. \& B. Z. Pozner, 1987, The leadership challenge, JosseyBass, San Francisco, CA.

[27].Kruse, K. ( 2013 ). What is leadership? Forbes Magazine 
cognizancejournal.com

Francis Hull Adams et al, Cognizance Journal of Multidisciplinary Studies, Vol.1, Issue.7, July 2021, pg. 46-64

[28].Leithwood, K., Seashore L. K., Anderson, S. \& Wahlstrom, K. (2004). How leadership influences student learning. (Review of research). The Wallace Foundation, Center for Applied Research and Educational Improvement and Ontario Institute for Studies in Education.

[29].Liu, Y. (2013). Organisational culture, leadership Behaviours and Employee Attitude in Chinese SMEs: Empirical Evidence. China-USA Business Review, 12, ( 11 ), 1085-1095

[30]. Marzano, R. J., Waters, T., \& McNulty B. A. (2005). School leadership that works: from research to results. Alexandria, VA: ASCD McREL

[31].Ndiku, D. (2004). Only seed leadership can save us from woes. The East African Standard, August 19th, Nairobi

[32].Newman, E. (2013). The Upgrading of Teacher Training Institutions to Colleges of Education. Issues and Prospect. African Journal of teacher Education. 3, (2), 6-9

[33].Nwana, O.C ( 1981 ). Introduction to Educational Research for students teachers. Ibadan. Heinemann Educational Books.

[34].Northouse, P. G. (2001). Leadership Theory and Practice, 2nd ed. Thousand Oaks, CA: Sage Publications.

[35].Peters, T. J., \& Waterman Jr., R. H. (2004). In search of excellence: Lessons from America's best-run companies. New York: Harper Collins Publishers.

[36].Ruben, B. D., Gigliotti, R. A. ( 2016 ). Leadership as social influence: An expanded view of leadership communication theory and practice. Journal of leadership and organisational Studies, 23, ( 4 ), 469-479

[37].Salim, S.A.(2002). Africa peace leadership and governance challenges. African news service, Addis Ababa, Ethiopia.

[38].Sapienzo, A. M. (1985). Believing is seeing: How culture influences the decisions top managers make. San Francisco: Jossey-Bass.

[39].Schein, E. H. (1992). Organisational culture and leadership (Second Edition ed.).San Francisco: JosseyBass Publishers.

[40].Standard, J. (2009). Cultural commitments in institutions. Leipein, Asian Publishers Inc.

[41].Stark, R. ( 2004 ). Sociology, $9^{\text {th }}$ ed. Belmont, USA. Thompson learning inc.

[42]. Students' Representative Council constitution (2015). Central University College. Retrieved on 05-13-15 from www.src.central.edu.gh/constitution

[43]. Students' Representative Council constitution (2016). University of Cape Town. Retrieved on 19-03-16 from www.uct.ac.za/SRCconstitution

[44].Students' Representative Council constitution (2013). Holy Child College of Education, Takoradi. SRC Secretariat

[45].Tetteh, P. M. (2010). Sociology. SOCI 304: Groups, organisations and the individual. Accra, Ghana. Centre for Distance Educaion, Institute of Continuing and Distance education, University of Ghana, Legon

[46].Ubben, G. C., Hughes, L. W., \& Norris, C. J. (2007). The principal: Creative leadership for excellence in schools. Boston, MA: Pearson Education.

[47].UCC SRC Constitution (2015). Membership of the SRC Committee. Cape Coast, SRC.

[48].Van Knippenberg, D. \& M. A. Hogg. (2003). A social identity model of leadership effectiveness in organisations. In B. Staw and R. M. Kramer (eds), Research in Organisational Behavior, 25, 245-297. JAI Press, Greenwich, CN.

[49]. Westwood, R. (1997). Harmony and patriarchy: The cultural basis for "paternalistic headship" among the overseas Chinese. Organisation Studies, 18, 445-480.

[50].Wilkins, A. L. (1983). The culture audit: A tool for understanding organisations. Organisational Dynamics, 12, (2), pp. 24-38.

[51].Yukl, G. (2006). Leadership in organisations (6th ed.). Upper Saddle River, NJ: Pearson Prentice Hall.

[52].Zeitchik, S. (2012). Ten ways to define leadership. Business New 